\title{
Growth performance, physiological and haematological parameters of West African Dwarf sheep fed Panicum-cassava peels supplemented with or without Leucaena-based multinutrient blocks
}

\author{
Aye P. A \\ Department of Animal Production and Health Sciences \\ Ekiti State University Ado- Ekiti, Nigeria \\ amokapius@yahoo.com
}

\begin{abstract}
The nutritional potential of Leucaena-based multinutrient blocks was validated by feeding them to twenty-four (24) yearling West African Dwarf (WAD) Sheep for twelve weeks. The dry matter intake (DMI) of sheep fed on the control diet was significantly $(P<0.05)$ different from those fed on diets supplemented with Leucaena -based MNBs. The mean weight gain of sheep fed LUMNB $(2.0 \pm 0.9 \mathrm{~kg})$, LPMNB $(1.9 \pm 0.2 \mathrm{~kg})$ and LUPMNB $(1.4 \pm 0.04 \mathrm{~kg})$ were significantly $(P<0.05)$ higher than those fed on the control diet $(0.7 \pm 0.2 \mathrm{~kg})$. Sheep fed on control diet had the lowest feed conversion ratio $(62.0 \pm 0.2)$ while sheep fed on supplemented MNBs had $20.5 \pm 0.1,22.5 \pm 1.2$ and $30.7 \pm 0.4$, for supplemental LUMNB, LPMNB, and LUPMNB, respectively. The highest feed conversion ratio was recorded on sheep fed LUMNB $(20.5 \pm 0.1)$. The dry matter intake of sheep fed LUMNB $\left(1637.33 \pm 3.4 \mathrm{~g}\right.$ day $\left.^{-1}\right)$, LPMNB $\left(1569.67 \pm 10.4 \mathrm{~g}^{-1} \mathrm{yy}^{-1}\right)$, LUPMNB $(1403.67 \pm 14.7 \mathrm{~g}$ day $\left.{ }^{1}\right)$ were significantly $(\bar{P}<0.05)$ higher than those fed control diet $\left(1102.0 \pm 9.6 \mathrm{~g} \mathrm{day}^{-1}\right)$. Sheep fed Panicum-cassava peels supplemented with LPMNB, LUPMNB, LUMNB had significant $(\mathrm{P}<$ $0.05)$ higher daily average gain values of $38.1,38.1,57.1 \mathrm{~g}$ respectively than those on control diets $(9.5+4.2 \mathrm{~g})$. The mean respiratory rates of sheep fed on Leucaena-based multinutrient blocks varied from $(23.0 \pm 1.0$ /minute to $23.3 \pm 1.2$ /minute) and these were significantly $(P<0.05)$ lower than those fed on the control diet $(25.7 \pm 0.6 /$ minute). The rectal temperature of sheep fed supplemented MNBs were not significantly $(P>0.05)$ different from those fed control diet. This shows that the rectal temperature were fairly constant. The pulse rates of sheep fed MNBs varied from $76.0 \pm 0.3$ pulse/minutes to $76.3 \pm 0.6$ pulse/minutes and these were significantly $(P<0.05)$ lower than those sheep fed control diet $(82.0 \pm 1.0$ pulse/minutes). Haematological variables measured showed that the PCV, RBC, WBC, HBC, ESR, MCH, MCHC, MCV, Lymphocytes, Neutrophils, Monocytes were significantly $(P<0.05)$ influenced by the dietary treatment. Generally, the haematological variables of the sheep fed Panicum-cassava peels ration supplemented with MNBs were higher than those fed control diet. The body length gain of sheep fed LUMNB $(19.0 \pm 4.1 \mathrm{~cm})$, LPMNB $(16.7 \pm 3.5 \mathrm{~cm})$, and LUPMNB $(13.7 \pm 4.7 \mathrm{~cm})$ were significantly $(P<0.05)$ higher than those sheep fed on the control diet $(9.6 \pm 1.2 \mathrm{~cm})$. Also the heart girth gain of sheep fed Panicum-cassava peels ration supplemented with LUMNB $(15.4 \pm 0.3 \mathrm{~cm})$, LUPMNB $(12.7 \pm 0.6 \mathrm{~cm})$, LPMNB $(12.1 \pm 0.3 \mathrm{~cm})$ were significantly $(P<0.05)$ higher than those sheep fed the control diet of Panicum-cassava peels ration. In the same vein, the height at wither gain of sheep fed basal diets of Panicum-cassava peels supplemented with LPMNB $(21.7 \pm 0.7 \mathrm{~cm})$, LUPMNB $(21.6 \pm 2.1 \mathrm{~cm})$, LUMNB $(20.7 \pm 0.3 \mathrm{~cm})$, were significantly $(P<0.05)$ higher than those sheep fed basal diet of Panicum-cassava peels alone $(6.3 \pm 0.7 \mathrm{~cm})$. Based on the performance, physiological and haematological indices, it was concluded that supplemental use of multinutrient blocks especially the LUMNB in feedlot of sheep offer tremendous potentials for increased mutton production in the sub-sahara region.
\end{abstract}

Key words: Growth, Physiology, Haematology, Leucaena, Multinutrient

\section{INTRODUCTION}

The effects on ruminants of imbalanced nutrient supply, in particular fermentable nitrogen and protein, include decreased rate of growth, low parturition rate, low birth weight, high lamb mortality, low weaning weight and reduced milk and wool production (Leng 
et al., 1991; Agbede, 2006). Therefore, to enhance small ruminant productivity in Nigeria and other developing countries south of Sahara alternative nutritional practices should include: feed supplementation by the use of multinutrient blocks containing fermentable nitrogen and sulphur and other microbial growth enhancement factors, (Leng et al., 1991; Ricca and Combellas, 1993) the enhancement of digestibility of crop residues; the increased use of fibrous residue by the manipulation of rumen functionality

Ruminants have a unique digestive system that allows them to utilise wastes and other types of byproducts as sources of dietary nutrients, which cannot be utilised, as nutrient sources by monogastric animals. Poultry wastes have been effectively used in maintenance, growth and finishing ruminant diets (Jacob et al., 1997).

The disappearance of food particles from the reticulorumen depends primarily on the rate of digestion. Higher fibre rations result in longer retention and lowered intakes (Adebowale and Ademosun 1981). Nwechue (2000) reported that the voluntary intake could also result from differences in ash contents where increased ash contents lower dry matter intake and digestibility.

In Nigeria, grazing on communal lands is the dominant feeding system and nutritive value is not a constraint during rainy season. However, during extended dry season especially in the Northern part of the country, the mature tropical grasses resemble crop residues in chemical composition and could adversely affect the rumen fermentative digestion with attendant low digestibility and utilization (Preston and Leng, 1984; 1986).

Multinutrient blocks, which are of no dietary importance to man could be utilized as supplements for sheep. The feed blocks represent a vast reservoir of cheap nutrients, particularly for ruminants.

Feeding Leucaena- based multinutrient blocks result in reduced feed cost, lowered price of animal products and contribute to self-sufficiency in protein, calcium, phosphorus and expensive nutrients in ruminant production.

Protein supplements like oil seed cakes (Alhassan, 1988) and leguminous browse plants such as Gliricidia and Leucaena (Ademosun et al., 1985) have been put to good use in boosting the productivity of sheep and goats. Feed block has been advocated as a panacea to protein and energy deficiencies in ruminants especially during the dry season (Onwuka, 1999). It has been demonstrated to improve dry matter intake and turn a Live-weight loss of $-53 \mathrm{~g} \mathrm{day}^{-1}$ to a gain of $+10 \mathrm{gday}^{-1}$ in lambs on a basal diet of wheat straw (Hendratno et al., 1989).

In the wet season, grasses grow luxuriantly and contain adequate protein needed for maintenance and production. However, as the rainy season progresses, the grasses become fibrous leading to reduction in nutritional qualities. Thus, multinutrient blocks supplementation will also be useful in the wet season. Further, during the cropping season in many communities in South Western Nigeria, small ruminants are restricted or tied in the homestead to prevent damage to crops. Thus, the owners of animals cut grass for them, which may not represent the best feed selection to ensure adequate growth. Therefore, multinutrient blocks supplementation is also necessary in the wet season as a form of supplementary nutrients.

The dry matter (DM) intake is an important factor in the utilization of feed by ruminant livestock and is a critical determination of energy intake and performance in small ruminants (Devendra and Burns, 1983).

This study is designed to validate the nutritional values of Leucaena- based multinutrient blocks using performance, physiological and haematological characteristics of West African dwarf sheep.

\section{MATERIALS AND METHODS}

Study Area: The experiment was carried out at the Small Ruminant Unit of Teaching and Research Farm of the Ekiti State University, Ado- Ekiti. The pens were cleaned and disinfected before the arrival of the animals.

Procurement of West African Dwarf (WAD) Sheep: Twenty-four yearlings WAD sheep weighing on average $11.2^{ \pm} 0.4 \mathrm{~kg}$ were purchased from the open markets in Ondo and Ekiti states of Nigeria. They were quarantined for thirty days during which routine treatment development at NAPRI (1984) and modified by Aye (2007) was applied.

Day 1: Prophylactic antibiotics treatment was given for 3 days using Kepro-oxylet and Tissue Culture Rinderpest Vaccine was also given.

Day 4: Broad spectrum anti-helminthics using Panacur and coccidiostat treatment using Prococc were administered for 3 days. 
Day 7: Animals were sprayed against ectoparasite using Asuntol.

Day 28: Levamisole and Asuntol were repeated for the helminths and ectoparasites respectively.

Day 30:Animals were put in their pens and were given Ivomec against mange.

Experimental layout and Animal management: The sheep pen was partitioned into twenty-four equidimentional units with planks. The sheep were weighed into their experimental units, efforts were made to ensure that all the treatments were balanced in body weight and age. This was done using the dentition and weight range methods (Devendra and Mcleroy, 1988; Adebowale et al., 1992). The design of the experiment was a completely randomised design. The animals were divided into four groups of six animals balanced for body weight and were randomly allocated to experimental dietary treatments. The sheep on treatments 1,2 and 3 were fed Panicum-Cassava peels rations supplemented with Leucaena + Poultry manure multinutrient blocks (LPMNB), Leucaena+urea+poultry manure multinutrient blocks (LUPMNB) and Leucaena+Urea multinutrient blocks (LUMNB) respectively. The sheep on treatment (4) were fed Panicum - Cassava peels ration without multinutrient block supplementation. The animals were fed on the supplemented diets for twelve weeks.

Linear Body measurements: The body length which is the average of left and right side measurements of the distance between the head of humerii and the distal end of the pubic bone were taken using a centimetre graduated tape with the animal standing on flat ground. The height at withers which is the distance between the most cranial palpable spinosus and the ground was determined on animal standing vertically straight. The heart girth was also measured as the body circumference just behind the fore legs (Hall, 1991; Orheruata and Olutogun, 1994; Herrera et al., 1996; Salako and Ngere, 2002). Each animal was restrained with the help of at least two assistants who helped to hold the animals in an unforced position. Each dimension was measured at least three times and the mean recorded in centimetres.

Weight Gain: All the animals were weighed at the beginning of the trial and subsequently every week for an assessment of the growth rate. Weighing of sheep was carried out with the aid of mobile metallic weighing crate. A standard $100 \mathrm{~kg}$ Salter scale was mounted on the weighing crate. Average daily gains were calculated from the weekly weights for individual WAD sheep over the entire period of the trial.

Feed Intake: During the twelve weeks of feeding trial, the animals were fed a weighed amount of feed and left over collected and weighed to determine amount of feed consumed by the animals.

\section{Haematology}

Blood Collection: Blood was collected from the jugular vein of the sheep at the start and two-week interval during the feeding trial for analysis. Blood was collected into a vial containing Ethylenediaminetetra-acetic acid (EDTA) which prevents coagulation by complexing $\mathrm{Ca}^{2+}$. The vials or bijoul bottles were immediately capped and the content mixed gently for about a minute by repeated inversion or rocking. The blood smears were prepared immediately after the collection.

Packed Cell Volume (Haematocrit): Packed cell volume (PCV) was determined by spinning about $75 \mu \mathrm{l}$ of each blood sample in heparinised capillary tubes in a haematocrit centrifuge for about 5 minutes. PCV was then read on haematocrit reader as described by Benson et al (1989) and Jain (1993).

Erythrocyte (RBC) Count: RBC was determined using haemocytometer method as described by Lamb (1981). The blood sample collected in each replicate was diluted at a ratio of 1:200 for RBC count using red cell diluting fluid. Samples of RBC were obtained using the relationship Red Blood Cell $/ \mu \mathrm{l}=$ Number of Cell counted x $5 \times 10 \times 200$

Haemoglobin Estimation: The haemoglobin content in the blood of each sheep was estimated using cyanomethaemoglobin method. $0.02 \mathrm{ml}$ of blood from each sheep was expelled into $4 \mathrm{ml}$ Drabkins Solution. The mixture was allowed to stand for 5 minutes for full colour development. Also, standard haemoglobin was prepared by diluting blood of known haemoglobin concentration as in the test samples. The test samples and standard were read on the colourimeter at 624 nanometer using green filter.

Sample haemoglobin concentration was obtained using this relationship:

Sample Haemoglobin $=$
$\frac{\text { Reading of test }}{\text { Haemoglobin Concentration }(\mathrm{g} / 100 \mathrm{ml})}$
Reading of Standard


Haematological indices also measured were erythrocyte sedimentation rate (ESR) Lymphocytes, neutrophils, monocytes, eosinophils, and basophils.

\section{Estimation of absolute Haemoglobin value:}

Mean Corpuscular Haemoglobin Concentration (MCHC): This expresses the concentration of haemoglobin in the red cell as compared to the concentration of haemoglobin in $100 \mathrm{~cm}^{3}$ of blood expressed in percentage (\%).

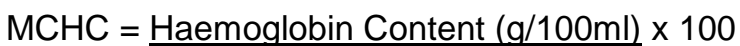

\section{PCV}

Mean Corpuscular Haemoglobin (MCH): This expresses the amount of haemoglobin in one red cell expressed in pictogram (pg)

$\mathrm{MCH}=\underline{\text { Haemoglobin Content }(\mathrm{g} / 100 \mathrm{ml})} \times \underline{100}$

$\mathrm{RBC}$

Mean Corpuscular Volume (MCV): This expresses the average red cell volume measured in cubic micron $\left(\mu^{3}\right)$

$$
\text { MCV }=\frac{\text { Packed Cell Volume }}{\text { RBC }} \times 10\left(\mu^{3}\right)
$$

\section{Physiological Parameters}

Respiratory Rate: Two independent counts of the respiratory (flank) movement were made and averaged to per minute measurement (Kelly, 1980: Pagot, 1992). This was done before the rectal temperature was taken to avoid excitement. A stopwatch was used to time the counts.

Rectal Temperature: This was taken on all animals on one day a week at $0700 \mathrm{~h}, 1230 \mathrm{~h}$ and $1730 \mathrm{~h}$ respectively using digital clinical thermometer (Troge Medical GMBH Hamburg. Germany). The thermometer was inserted into the rectum of the animals at a depth of $5 \mathrm{~cm}$ with the bulb touching the mucosa wall of the rectum for one minute. It was removed and read. The thermometer was then cleaned with methylated spirit (Kelly 1980; Fasehun et al 1995).

Pulse Rate: This was taken thrice at 0700h, $1230 \mathrm{~h}$ and $1730 \mathrm{~h}$ local time on all animals once a week. A stopwatch was also used to time the count. Pulse rate were taken from the femoral artery (Ogunmola, 1981; Pagot, 1992).

Ambient Temperature: The minimum and maximum temperatures were taken using six's thermometer
(Gallenkamp THR - 600 - S) on one day a week at $0700 \mathrm{~h}$ and $1730 \mathrm{~h}$ respectively. The thermometers were reset by a magnet for next reading.

Chemical and statistical Analyses: For the chemical analysis all values were mean for triplicate determinations and where applicable the coefficient of variations between plants species were established (Steel and Torrie, 1980). The dry matter of the Panicum maximum and Cassava peels were determined by the procedures of AOAC (1995). All group means and the ANOVA of data collected were determined using Minitab Statistical Package version 10.2 (Minitab Inc. USA)

\section{RESULTS}

Performance of experimental sheep: The effect of the various dietary treatments on weight gain, feed consumption and feed efficiency and body measurements gain are shown in Tables 6 and 7 . The dry matter intake (DMI) of sheep fed on the control was significantly $(P<0.05)$ different from those fed on diets supplemented with Leucaena based multinutrient blocks (MNBs).

The mean weight gain (WG), heart girth gain (HGG), height at wither gain (HWG), body length gain (BLG) and feed conversion ratio (FCR) were significantly $(P$ $<0.05)$ influenced by the dietary treatments. For instance, the weight gain of sheep fed LUMNB $(2.0 \pm$ $0.9 \mathrm{~kg})$, LPMNB $(1.9 \pm 0.2 \mathrm{~kg})$, and LUPMNB (1.4 \pm $0.4 \mathrm{~kg})$ were significantly $(P<0.05)$ higher than those fed on the control diet $(0.7 \pm 0.2 \mathrm{~kg})$. Of the entire multinutrient blocks (MNBs) made from Leucaena leaf residue, sheep fed on supplemental LUMNB had the highest weight gain, strictly followed by those fed on supplemental LPMNB and those fed on supplemental LUPMNB had the least weight gain.

The feed efficiency of sheep fed on the supplemental multinutrients blocks were not the same with that of control. Sheep fed on control diet had the lowest feed conversion ratio $(50.6 \pm 0.2)$ while sheep fed on supplemental multinutrients blocks had $(20.6 \pm 0.1)$, $(21.3 \pm 1.2)$ and $(30.6 \pm 0.4)$, for supplemental LUMNB, LPMNB and LUPMB respectively. The highest feed conversion ratio was recorded on sheep fed LUMNB $(20.6 \pm 0.1)$.

The heart girth gain (HGG), height at wither gain (HWG) and the body length gain (BLG) of sheep fed on the control were significantly $(P<0.05)$ different from those fed on diets supplemented with multinutrient blocks. For instance, the body length gain of sheep fed LUMNB $(19.0 \pm 4.1 \mathrm{~cm})$, LPMNB 
$(16.7 \pm 3.5 \mathrm{~cm})$ and LUPMNB $(13.7 \pm 4.7 \mathrm{~cm})$ were significantly $(P<0.05)$ higher than those sheep fed on the control diet $(9.6 \pm 1.2 \mathrm{~cm})$.

Of all the entire sheep fed MNBs made from Leucaena leaf residue, sheep fed on supplemental LUMNB had the highest body length gain, followed strictly by LPMNB and sheep fed on supplemental LUPMNB had the least body length gain.

Physiological Parameters: The mean weekly respiratory rates of the sheep are presented in Table 8. The mean respiratory rates of sheep fed on Leucaena- based multinutrient blocks ranged from $23.0 \pm 1.0 /$ minute to $23.3 \pm 1.2 /$ minute and these were significantly $(P<0.05)$ lower than those fed on the control diet $(25.7 \pm 0.6 /$ minute $)$.

Table 9 shows that rectal temperature measured during the experimental period were not significantly $(P>0.05)$ influenced by the treatments. The rectal temperature in sheep fed Leucaena-based multinutrient blocks varies from $39.4 \pm 0.0^{\circ} \mathrm{C}$ to 39.5 $\pm 0.1^{\circ} \mathrm{C}$ and with control treatment $39.8 \pm 0.0^{\circ} \mathrm{C}$. This shows that the rectal temperatures were fairly constant.

The pulse rates of rams are presented in Table 10. The pulse rate varied from $76.0 \pm 0.4$ pulse/minute to $76.3 \pm 0.6$ pulse/minute on rams fed Leucaena based multinutrient blocks and with the control treatment value of $82.0 \pm 1.0$ pulse/minute. This suggests that the pulse rates were significantly $(P<0.05)$ affected by the multinutrient blocks.

Haematological Variables: Table 11 presents the haematological variables of sheep fed Leucaena based multinutrient blocks. The Packed cell volume (PCV) value for rams fed MNBs range from $31.3 \pm$ $3.2 \%$ in LUPMNB to $33.0+3.0 \%$ in LUMNB compared to PCV value of $27.3 \pm 2.5 \%$ in the control diet. The Red blood cell varied from $9.8 \pm$ $0.7 \times 10^{6} \mathrm{~mm}^{-1}$ in LPMNB to $10.8 \pm 1.0 \times 10^{6} \mathrm{~mm}^{-1}$ in LUMNB with control treatment having the value of 7.7 $\pm 0.9 \times 10^{6} \mathrm{~mm}^{-1}$. The White blood cell was highest $\left(10.3 \pm 0.5 \times 10^{3} \mathrm{~mm}^{-1}\right)$ in LPMNB while the least $(6.1$ $+02 \bar{X} 10^{3} \mathrm{~mm}^{-1}$ ) value was recorded in rams fed control treatment.

Hbc was lowest in the sheep fed the Pannicum cassava peel ration supplemented with LUPMNB (7.4

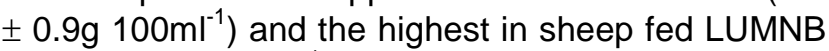

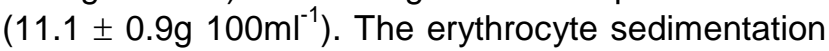
rate $(\mathrm{mm} / \mathrm{hr})$ varied between $0.3 \pm 0.1$ in control treatment and $1.1 \pm 0.4$ in LUPMNB. The MCHC (\%) ranged from $31.5 \pm 0.1$ in rams fed control to $33.7 \pm$ 0.3 in rams fed LUMNB, while the $\mathrm{MCH}(\mathrm{pg})$ of rams fed supplemented LPMNB was the highest (11.2 \pm 1.2). The MCV $\left(\mu \mathrm{m}^{-3}\right)$ was also highest in rams fed LPMNB (33.4 \pm 3.7$)$. The Lymphocyte value for LPMNB, LUPMNB and LUMNB which were 59.3 \pm 3.2 , $59.3 \pm 2.1$ and $56.3 \pm 3.5$ respectively were not significantly different but the value were significantly $(\mathrm{P}<0.05)$ higher than the value from control treatment. Result on Neutrophils (\%) showed significant $(P<0.05)$ treatment effect with sheep fed Panicum-cassava peels ration supplemented with Leucaena-based multinutrient blocks having higher Neutrophils values $(26.7 \pm 1.2$ to $29.3 \pm 0.6)$ than the value from control treatment $(22.0 \pm 1.0)$. The mean Monocytes values (\%) of the LPMNB, LUPMNB and LUMNB were significantly $(P<0.05)$ higher than the rams fed control diet. However, the monocytes values of LPMNB, LUPMNB and LUMNB were statistically the same. The mean Oesinophil and Basophils values of the multinutrient blocks and the control treatment were not significantly different $(P>$ 0.05). The rams fed control diet showed the least values for all the haematological variables. 
Am. J. Food. Nutr, 2013, 3(3): 135-146

Table 1: Nutrients Composition in Panicum maximum and Cassava peels

\begin{tabular}{|c|c|c|c|}
\hline COMPOSITION & PANICUM MAXIMUM & CASSAVA PEELS & COEFFICIENT OF VARIATION \\
\hline Dry Matter $\left(\mathrm{g} \mathrm{kg}^{-1}\right)$ & $914.7 \pm 0.0$ & $945.3 \pm 0.2$ & 2.33 \\
\hline Crude Protein $\left(\mathrm{g} \mathrm{kg}^{-1}\right)$ & $161.4 \pm 0.5$ & $69.1 \pm 0.5$ & 56.61 \\
\hline Ash $\left(\mathrm{g} \mathrm{kg}^{-1}\right)$ & $72.4 \pm 0.1$ & $69.0 \pm 0.0$ & 3.39 \\
\hline Crude Fibre $\left(\mathrm{g} \mathrm{kg}^{-1}\right)$ & $352.1 \pm 0.0$ & $109.5 \pm 0.0$ & 74.32 \\
\hline Ether Extract $\left(\mathrm{g} \mathrm{kg}^{-1}\right)$ & $53.2 \pm 0.1$ & $71.2 \pm 0.0$ & 20.47 \\
\hline Nitrogen Free Extract $\left(\mathrm{g} \mathrm{kg}^{-1}\right)$ & $361.0 \pm 0.5$ & $681.2 \pm 0.3$ & 43.45 \\
\hline Gross Energy (MJ kg ${ }^{-1}$ ) & $12.0 \pm 0.1$ & $17.47 \pm 0.0$ & 26.26 \\
\hline Calcium (mg kg $\left.{ }^{-1}\right)$ & 512.98 & 135.47 & 82.32 \\
\hline Sodium (mg kg ${ }^{-1}$ ) & 205.88 & 174.98 & 11.48 \\
\hline Potassium (mg kg ${ }^{-1}$ ) & 519.78 & 156.16 & 76.07 \\
\hline Phosphorus (mg kg ${ }^{-1}$ ) & 1598.50 & 64.20 & 130.50 \\
\hline Magnesium (mg kg $\left.{ }^{-1}\right)$ & 148.74 & 122.30 & 13.80 \\
\hline Iron $\left(\mathrm{mg} \mathrm{kg}^{-1}\right)$ & 95.23 & 7.53 & 120.69 \\
\hline Magnesium $\left(\mathrm{mg} \mathrm{kg}^{-1}\right)$ & ND & 3.76 & - \\
\hline Zinc $\left(\mathrm{mg} \mathrm{kg}^{-1}\right)$ & 102.49 & 77.14 & 19.96 \\
\hline Copper $\left(\mathrm{mg} \mathrm{kg}^{-1}\right)$ & ND & ND & \\
\hline
\end{tabular}

Table 2: Ingredient Composition (\%) of Multi-nutrient blocks

\begin{tabular}{llll}
\hline Ingredients & LPMNB & Treatments & LUMNB \\
\hline Molasses & 40 & 40 & 40 \\
Urea & - & 5 & 10 \\
Poultry manure & 10 & 5 & - \\
Salt & 5 & 5 & 5 \\
Cement & 15 & 15 & 15 \\
Leucaena residue & 30 & 30 & 30 \\
Total & 100 & 100 & 100 \\
\hline
\end{tabular}


Am. J. Food. Nutr, 2013, 3(3): 135-146

Table 3 Proximate: Composition $\left(\mathrm{g} \mathrm{Kg}^{-1}\right)$, Gross energy $\left(\mathrm{MJKg}^{-1}\right)$ and strength of multinutrient blocks

\begin{tabular}{|c|c|c|c|c|c|c|c|c|}
\hline Treatment & DM & CP & CF & EE & ASH & NFE & Gross energy & Strength \\
\hline LPMNB & $784.5 \pm 0.03$ & $54.4 \pm 0.59$ & $66.0 \pm 071$ & $70.2 \pm 0.01$ & $28.56 \_0.01$ & $523.8 \pm 6.28$ & 12.74 & Strong \\
\hline LUPMNB & $754.8 \pm 0.01$ & $195.7 \pm 1.19$ & $48.5 \pm 0.42$ & $72.3 \pm 0.02$ & $248.4 \pm 0.2$ & $414.1 \pm 0.49$ & 13.58 & Strong \\
\hline LUMNB & $769.7 \pm 0.04$ & $328.2 \pm 0.61$ & $47.5 \pm 0.01$ & $44.1 \pm 0.01$ & $248.4 \pm 0.3$ & $331.8 \pm 0.38$ & 15.33 & Very strong \\
\hline MEAN & 762.0 & 188.6 & 71.8 & 70.8 & 281.2 & 387.6 & 13.89 & \\
\hline S.D & 2.72 & 13.19 & 2.69 & 1.60 & 2.89 & 10.53 & 1.51 & \\
\hline CV & 3.57 & 69.94 & 37.47 & 22.60 & 10.28 & 27.17 & 10.87 & \\
\hline
\end{tabular}

\begin{tabular}{|c|c|c|c|c|c|c|c|c|c|c|}
\hline Treatment & $\mathrm{Na}$ & $\mathbf{P}$ & $\mathrm{K}$ & $\mathrm{Ca}$ & $\mathrm{Mg}$ & $\mathbf{S}$ & Zn & $\mathrm{Fe}$ & $\mathrm{Cu}$ & Mn \\
\hline LPMNB & 648.20 & 210.70 & 623.30 & 971.40 & 135.70 & 121.43 & 214.20 & 57.10 & ND & 21.40 \\
\hline LUPMNB & 635.40 & 107.10 & 628.50 & 950.00 & 121.40 & 62.50 & 357.10 & 85.70 & ND & 14.30 \\
\hline LUMNB & 432.30 & 215.60 & 563.20 & 737.50 & 225.00 & 45.31 & 131.30 & 68.80 & 0.06 & 21.80 \\
\hline MEAN & 667.20 & 133.8 & 705.50 & 845.90 & 164.10 & 90.68 & 257.80 & 148.60 & 0.07 & 34.60 \\
\hline SD & 148.70 & 74.45 & 139.89 & 104.60 & 39.10 & 42.10 & 109.30 & 93.80 & 0.00 & 17.70 \\
\hline CV & 22.30 & 55.60 & 19.80 & 12.40 & 23.80 & 46.4 & 42.40 & 63.10 & 20.20 & 51.0 \\
\hline
\end{tabular}

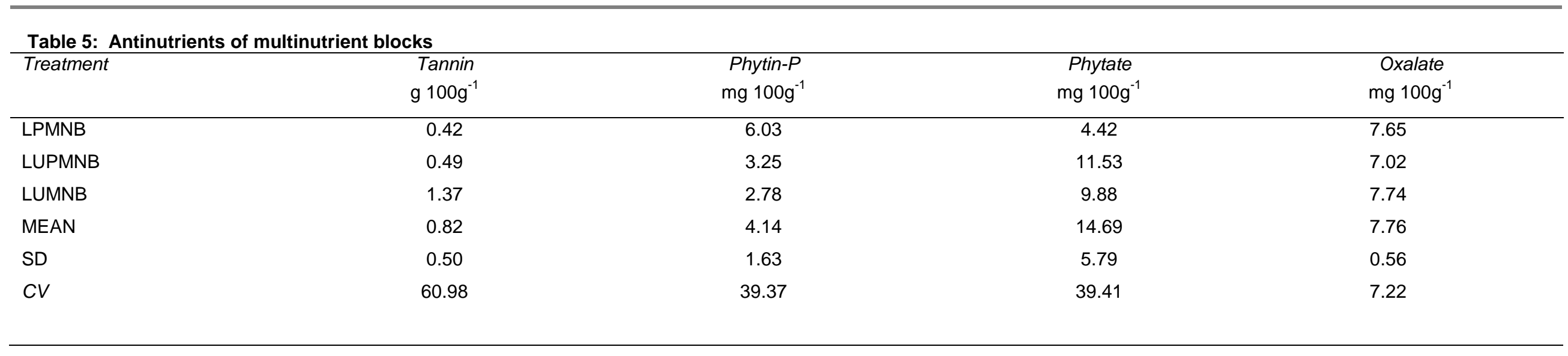


Table 6: Performance of sheep fed Panicum - Cassava peel ration supplemented with Leucaena based multinutrient blocks (kg)

\begin{tabular}{|c|c|c|c|c|c|c|c|c|}
\hline Treatment & $\begin{array}{c}\text { Dry matter } \\
\text { Intake }\end{array}$ & Initial wt & Final wt & Weight gain & Initial $\mathbf{W}^{0.15}$ & Final $\mathbf{W}^{0.15}$ & $\mathrm{~W}^{0.15}$ gain & Feed conversion ratio \\
\hline LPMNB & $40.5 \pm 1.9^{a}$ & $11.6 \pm 1.3$ & $13.5 \pm 1.2$ & $1.9 \pm 0.2^{a}$ & $6.2 \pm 0.9$ & $7.1 \pm 0.8^{a}$ & $0.9 \pm 0.3^{a}$ & $21.3 \pm 1.2^{c}$ \\
\hline LUPMNB & $37.2 \pm 0.7^{b}$ & $10.9 \pm 1.3$ & $12.4 \pm 1.3$ & $1.4 \pm 0.4^{\mathrm{b}}$ & $6.0 \pm 1.0$ & $6.6 \pm 0.9^{b}$ & $0.6 \pm 0.4^{b}$ & $26.6 \pm 0.4^{\mathrm{b}}$ \\
\hline LUMNB & $41.1 \pm 2.0^{\mathrm{a}}$ & $11.7 \pm 1.2$ & $13.7 \pm 0.4$ & $2.0 \pm 0.9^{a}$ & $6.2 \pm 0.9$ & $7.1 \pm 0.3^{a}$ & $0.9 \pm 0.4^{\mathrm{a}}$ & $20.6 \pm 0.1^{c}$ \\
\hline CONTROL & $35.4 \pm 0.2^{\mathrm{C}}$ & $11.1 \pm 0.9$ & $11.8 \pm 0.7$ & $0.7 \pm 0.2^{\mathrm{c}}$ & $6.0 \pm 0.7$ & $6.4 \pm 0.5^{\mathrm{b}}$ & $0.4 \pm 0.2^{c}$ & $50.6 \pm 0.2^{\mathrm{a}}$ \\
\hline
\end{tabular}

Table 7: Morphostructural differentiation of sheep fed Panicum - Cassava peels ration supplemented with Leucaena-based multinutrient blocks.

\begin{tabular}{|c|c|c|c|c|c|c|c|c|c|}
\hline Treatment & $\begin{array}{l}\text { Initial Heart } \\
\text { Girth }(\mathbf{c m})\end{array}$ & $\begin{array}{l}\text { Final Heart } \\
\text { Girth }(\mathrm{cm})\end{array}$ & $\begin{array}{l}\text { Heart Girth } \\
\text { gain }(\mathrm{cm})\end{array}$ & $\begin{array}{l}\text { Initial Height at } \\
\text { Wither }(\mathbf{c m})\end{array}$ & $\begin{array}{l}\text { Final Height at } \\
\text { Wither }(\mathrm{cm})\end{array}$ & $\begin{array}{l}\text { Height at Wither } \\
\text { gain }(\mathrm{cm})\end{array}$ & $\begin{array}{l}\text { Initial Body } \\
\text { length (cm) }\end{array}$ & $\begin{array}{l}\text { Final Body } \\
\text { length (cm) }\end{array}$ & $\begin{array}{l}\text { Body Length } \\
\text { gain (cm }\end{array}$ \\
\hline LPMNB & $45.3 \pm 7.0$ & $57.3 \pm 5.0$ & $12.1 \pm 0.3^{b}$ & $53.0 \pm 1.0$ & $74.7 \pm 1.2$ & $21.7 \pm 0.7^{a}$ & $63.3 \pm 6.4$ & $80.0 \pm 5.3$ & $16.7 \pm 3.5^{\mathrm{a}}$ \\
\hline LUPMNB & $46.0 \pm 5.3$ & $58.7 \pm 4.0$ & $12.7 \pm 0.6^{\mathrm{b}}$ & $51.7 \pm 1.5$ & $73.3 \pm 1.2$ & $21.6 \pm 2.1^{\mathrm{a}}$ & $65.3 \pm 4.9$ & $79.0 \pm 3.6$ & $13.7 \pm 4.7^{\mathrm{b}}$ \\
\hline LUMNB & $45.3 \pm 8.0$ & $60.7 \pm 8.0$ & $15.4 \pm 0.3^{a}$ & $50.3 \pm 3.5$ & $71.0 \pm 4.4$ & $20.7 \pm 0.3^{a}$ & $66.7 \pm 2.3$ & $85.7 \pm 6.1$ & $19.0 \pm 4.1^{a}$ \\
\hline CONTROL & $44.0 \pm 0.0$ & $52.7 \pm 2.1$ & $8.7 \pm 0.6^{c}$ & $50.0 \pm 2.0$ & $56.3 \pm 2.3$ & $6.3 \pm 0.7^{\mathrm{b}}$ & $62.7 \pm 4.6$ & $72.3 \pm 4.0$ & $9.6 \pm 1.2^{c}$ \\
\hline
\end{tabular}


Table 8: Weekly Mean Respiratory Rate/Minute of Rams fed Panicum-Cassava peels ration supplemented with Leucaena-based multinutrient blocks

\begin{tabular}{|c|c|c|c|c|c|c|c|c|c|c|c|c|c|}
\hline \multirow{2}{*}{ Treatment } & \multicolumn{12}{|c|}{ Weekly Means } & \multirow{2}{*}{$\begin{array}{l}\text { Overall } \\
\text { Mean }\end{array}$} \\
\hline & 1 & 2 & 3 & 4 & 5 & 6 & 7 & 8 & 9 & 10 & 11 & 12 & \\
\hline LPMNB & $22.8 \pm 0.8$ & $22.5 \pm 0.9$ & $22.4 \pm 1.2$ & $22.7 \pm 1.0$ & $23.1 \pm 0.5$ & $23.4 \pm 0.6$ & $23.3 \pm 0.3$ & $23.8 \pm 0.1$ & $22.9 \pm 0.3$ & $23.5 \pm 0.2$ & $23.0 \pm 0.5$ & $23.0 \pm 1.0$ & $23.0+1.0^{b}$ \\
\hline LUPMNB & $23.6 \pm 0.3$ & $23.1 \pm 0.3$ & $23.1 \pm 0.5$ & $23.5 \pm 0.2$ & $23.2 \pm 0.2$ & $23.4 \pm 0.3$ & $23.5 \pm 0.6$ & $24.0 \pm 0.5$ & $23.5 \pm 0.4$ & $23.1 \pm 0.1$ & $23.4 \pm 0.3$ & $23.3 \pm 0 . .2$ & $23.3 \pm 0.6^{\mathrm{b}}$ \\
\hline LUMNB & $23.3 \pm 1.0$ & $23.3 \pm 0.8$ & $23.1 \pm 1.3$ & $23.2 \pm 1.0$ & $23.1 \pm 1.3$ & $23.3 \pm 0.3$ & $23.8 \pm 0.2$ & $23.7 \pm 0.2$ & $23.2 \pm 0.2$ & $23.7 \pm 0.3$ & $23.4 \pm 0.3$ & $23.1 \pm 0.1$ & $23.3 \pm 1.2^{\mathrm{b}}$ \\
\hline CONTROL & $24.0 \pm .3$ & $25.9 \pm 0.4$ & $26.6 \pm 0.3$ & $25.9 \pm 0.3$ & $25.8 \pm 0.1$ & $26.7 \pm 0.2$ & $26.0 \pm 0.4$ & $25.6 \pm 0.3$ & $26.3 \pm 0.2$ & $26.9 \pm 0.1$ & $25.8 \pm 0.2$ & $26.3 \pm 0.1$ & $25.7 \pm 0.6^{\mathrm{a}}$ \\
\hline
\end{tabular}

Table 9: Rectal Temperature $\left({ }^{\circ} \mathrm{C}\right)$ of Rams fed Panicum-Cassava peels ration supplemented with Leucaena based multinutrient blocks.

\begin{tabular}{|c|c|c|c|c|c|c|c|c|c|c|c|c|c|}
\hline \multirow[t]{2}{*}{ Treatment } & \multicolumn{11}{|c|}{ Weekly Means } & \multirow[b]{2}{*}{12} & \multirow{2}{*}{$\begin{array}{l}\text { Overall } \\
\text { Mean }\end{array}$} \\
\hline & 1 & 2 & 3 & 4 & 5 & 6 & 7 & 8 & 9 & 10 & 11 & & \\
\hline LPMNB & $39.3 \pm 0.0$ & $39.5 \pm 0.1$ & $39.4 \pm 0.0$ & $39.6 \pm 0.0$ & $39.5 \pm 0.1$ & $39.6 \pm 0.1$ & $39.4 \pm 0.1$ & $39.5 \pm 0.1$ & $39.4 \pm 0.1$ & $39.5 \pm 0.0$ & $39.4 \pm 0.1$ & $39.4 \pm 0.2$ & $39.5 \pm 0.1$ \\
\hline LUPMNB & $39.4 \pm 0.1$ & $39.3 \pm 0.1$ & $39.3 \pm 0.0$ & $39.4 \pm 0.0$ & $39.5 \pm 0.1$ & $39.4 \pm 0.0$ & $39.4 \pm 0.1$ & $39.3 \pm 0.0$ & $39.3 \pm 0.1$ & $39.5 \pm 0.0$ & $39.4 \pm 0.1$ & $39.3 \pm 0.1$ & $39.4 \pm 0.0$ \\
\hline LUMNB & $39.7 \pm 0.0$ & $39.7 \pm 0.1$ & $39.4 \pm 0.0$ & $39.4 \pm 0.0$ & $39.4 \pm 0.0$ & $39.5 \pm 0.1$ & $39.3 \pm 0.1$ & $39.3 \pm 0.1$ & $39.3 \pm 0.1$ & $39.4 \pm 0.0$ & $39.4 \pm 0.1$ & $39.3 \pm 0.0$ & $39.4 \pm 0.1$ \\
\hline CONTROL & $39.7 \pm 0.0$ & $39.9 \pm 0.0$ & $39.8 \pm 0.0$ & $39.9 \pm 0.1$ & $39.9 \pm 0.1$ & $39.8 \pm 0.0$ & $40.0 \pm 0.1$ & $40.0 \pm 0.1$ & $39.7 \pm 0.0$ & $39.9 \pm 0.0$ & $39.8 \pm 0.1$ & $39.7 \pm 0.1$ & $39.8 \pm 0.0$ \\
\hline
\end{tabular}


Table 10: Pulse Rate/minute of Ram fed Panicum-Cassava peels ration supplemented with Leucaena - based multinutrient

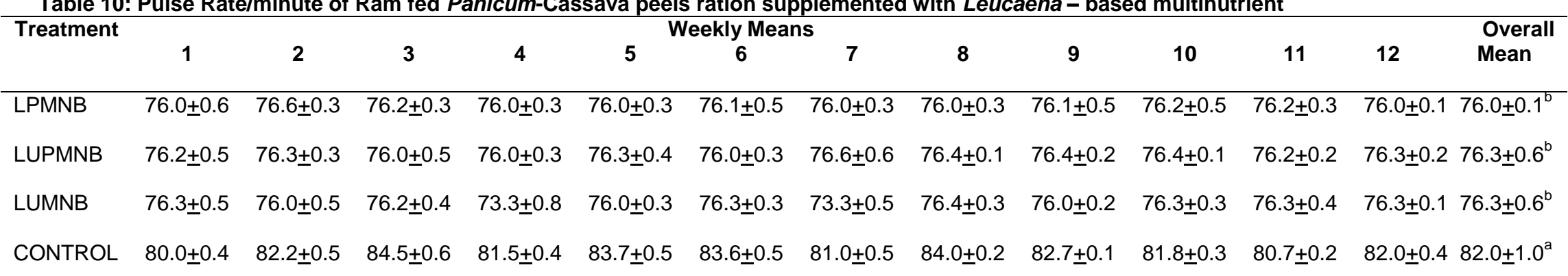

Table 11: Haematological indices of Rams fed Panicum-Cassava peels ration supplemented with Leucaena based multinutrient blocks

\begin{tabular}{|c|c|c|c|c|}
\hline Parameters & LPMNB & LUPMNB & LUMNB & Control \\
\hline Packed cell volume (\%) (PCV) & $32.3 \pm 4.5^{\mathrm{a}}$ & $31.3 \pm 3.2^{\mathrm{a}}$ & $33.0 \pm 3.0^{\mathrm{a}}$ & $27.3 \pm 2.5^{\mathrm{b}}$ \\
\hline Red Blood cell (x $10^{6} \mathrm{~mm}^{-1} 0$ (RBC) & $9.8 \pm 0.7^{\mathrm{a}}$ & $10.6 \pm 1.3^{\mathrm{a}}$ & $10.8 \pm 1.0^{\mathrm{a}}$ & $7.7 \pm 0.9^{b}$ \\
\hline White blood cell $\left(\times 10^{3} \mathrm{~mm}^{-1}\right) \quad(\mathrm{WBC})$ & $10.3 \pm 0.5^{\mathrm{a}}$ & $7.9 \pm 1.1^{\mathrm{b}}$ & $6.5 \pm 0.8^{c}$ & $6.1 \pm 0.2^{c}$ \\
\hline Haemoglobin concentration $\left(\mathrm{gm} 100 \mathrm{~mm}^{-1}\right) \quad \mathrm{Hb}$ & $10.8 \pm 1.5^{\mathrm{a}}$ & $7.4 \pm 0.9^{b}$ & $11.1 \pm 0.9^{a}$ & $8.6 \pm 0.8^{b}$ \\
\hline Erythrocyte sedimentation rate $(\mathrm{mm} / \mathrm{hr}) \quad(\mathrm{ESR})$ & $0.6 \pm 0.5^{\mathrm{b}}$ & $1.1 \pm 0.4^{\mathrm{a}}$ & $0.4 \pm 0.2^{\mathrm{b}}$ & $0.3 \pm 0.1^{\mathrm{b}}$ \\
\hline Mean Corpuscular haemoglobin conc. (\%) MCHC & $33.3 \pm 0.1^{\mathrm{a}}$ & $33.2 \pm 0.4^{\mathrm{a}}$ & $33.7 \pm 0.3^{a}$ & $38.4 \pm 1.2^{\mathrm{b}}$ \\
\hline Mean Corpuscular Haemoglobin (pg) (MCH) & $11.2 \pm 1.2^{\mathrm{a}}$ & $9.9 \pm 1.1^{\mathrm{b}}$ & $10.2 \pm 1.3^{\mathrm{a}}$ & $9.6 \pm 0.4^{\mathrm{b}}$ \\
\hline Mean Corpuscular volume $\left(\mu \mathrm{m}^{-3}\right)$ (MCV) & $33.4 \pm 3.7^{\mathrm{a}}$ & $29.8 \pm 3.1^{\mathrm{b}}$ & $30.7 \pm 3.8^{\mathrm{b}}$ & $28.6 \pm 1.0^{c}$ \\
\hline Lymphocyte (\%) & $59.3 \pm 3.2^{\mathrm{a}}$ & $59.3 \pm 2.1^{\mathrm{a}}$ & $56.3 \pm 3.5^{\mathrm{b}}$ & $46.3 \pm 1.5^{\mathrm{c}}$ \\
\hline Neutrophils (\%) & $27.3 \pm 2.1^{\mathrm{a}}$ & $26.7 \pm 1.2^{\mathrm{a}}$ & $29.3 \pm 0.6^{\mathrm{a}}$ & $22.0 \pm 1.0^{\mathrm{b}}$ \\
\hline Monocytes (\%) & $9.0 \pm 1.0^{\mathrm{a}}$ & $9.0 \pm 1.0^{\mathrm{a}}$ & $10.0 \pm 1.0^{\mathrm{a}}$ & $7.0 \pm 1.0^{\mathrm{b}}$ \\
\hline Eosinophils (\%) & $3.3 \pm 0.6$ & $4.3 \pm 2.1$ & $4.3 \pm 0.6$ & $2.7 \pm 0.6$ \\
\hline Basophils (\%) & $1.0 \pm 0.0$ & $1.0 \pm 0.0$ & $1.0 \pm 1.0$ & $0.3 \pm 0.6$ \\
\hline
\end{tabular}




\section{REFERENCES}

Adebowale C. A. and Ademosun A. A. (1981) Studies on the utilization of brewers dry grains by sheep and goats in growth trials. Bull. Anim. Hlth. Afr. 29:365-370.

Adebowale, E.A; A.A. Taiwo and J.F.D Green-halgh (1992) Nutritional survey of small ruminant production in Oyo State (Nigeria). In: A.O Ayeni and H.G. Bosman (Eds.). Goats Production System in Humid Tropics. Proc. Internal. Workshop Obafemi Awolowo University (OAU) Ile-Ife, Nigeria, 6-9 July 1992. pp 187-194

Ademosun, A.A; Jansen, H.J. and Van Hontert V. (1985) Goat management research at the University of Ife. In: Sumberg J.E. and Cassaday K. (eds) Sheep and goats in humid West Africa pp 34-37.

Agbede J. O. (2006) Characterization of leaf meals, protein concentration and residues from some tropical leguminous plants. J. Sci. Food Agric 86:22-82.

Agbede J. O. and Aletor V. A. (2003) Evaluation of fish meal replaced with leaf protein concentrate from Gliricidia in diets for broiler-chicks. Effect on performance, muscle growth and haematology and serum metabolites. International Journal of Poultry Science 2(4):242-250.

Aletor V. A. and Egberongbe O. (1992) Feeding differently processed Soyabean. Part 2: An assesment of haematological responses in the characteristics, haematology and sepium chemistry of chickens. Die Nahrung 36:364-369.

Alhassan W.S. (1988) The potential of Agro-industrial byproducts and crop residues for Sheep and goat production in Nigeria. In: I.F Adu, O.A. Osinowo, B.B.A. Taiwo and W.S. Alhassan (Eds.) Small ruminant production in Nigeria. Proc. National Conference on Small Ruminant Production Zaria, 6-10 October 1985. pp 165-183.

Anderson B. E. and Jonasson H. (1993) Temperature Regulation and Environmental Physiology. In: Swenson M. T. and Reece W. O. (eds) Physiology of Domestic Animals 11th edition. Pp. 2188-2189.

AOAC (1995) Official Methods of Analysis. 16th edn. (Association of Official Analytical Chemists Arlington, $\mathrm{VA})$

Aye P. A. (1998) The effects of two management systems on some physiological parameters and growth rate of the West African Dwarf goats. M. Tech. Thesis. Federal University of Technology Akure, Nigeria.

Aye P. A. (2004) Effect of Management Systems on the growth performance of West African Dwarf Goats. Proceedings 9th annual ASAN Conference. Sept. 13162004 Abakaliki. Pp 162-164.

Aye P. A(2007) Production of multinutrient blocks for ruminants and alcohol from the waste products of Leucaena and Gliricidia leaves using local technologies. Ph.D Thesis. Federal University of Technology Akure,Nigeria.

Devendra C. and Burns M. (1983) Goat and Sheep production in the tropics. Commonwealth Agric. Bureavx, Farnham Royal Bucks, England.

Devendra C. and Mcleroy G. B. (1988) Goats and Sheep production in the Tropics. London. ELBS Ed. longman pp 105-115.

Fasheun T. A.; Ologun A. G.; Eyoh D. B.; Oyeleye A. K. and Isin S. (1995) Physiological responses of growing large White boars in three management environments. Int. J. Biometeorol 38:98-101.

Habib W. Basit Ali Shah S.; Wahidullah W. and Ghuftranullah (1991) The importance of urea-molasses blocks and by-pass protein in animal production. The situation in Pakistan. 133-145. In Isotope and Related Techniques in Animal Production and Health by International Atomic Energy. Vienna.

Hadjipanayiotou M.; Verhaeghe L.; Allen M.; Kronfoleh A. R.; Labban L. M.; Shurbaji A.; Al-Wadi M.; Dassouki M.; Shaker B. and Amin M. (1993a) Urea blocks. I. Methodology of block making and different formulae tested in Syria. Livestock Research for Rural Development 5(3).

Hadjipanayiotou M.; Verhaeghe L.; Kronfoleh A. R.; Labban L. M.; Amin M.; Al-Wadi M.; Badran A.; Dawa K.; Shubaji A.; Houssein M.; Malki G.; Naigin T.; Merawi A. R. and Harres A. K. (1993b) Urea blocks. II. Performance of cattle and sheep offered urea blocks in Syria. Livestock Research for Rural Development 5(3).

Hall: S. J. G. (1991) Body dimensions of Nigerian cattle, sheep and goats. Anim. Prod. 53: 61-69.

Hendratno, C; Abidin, Z; Bahaudin, R; Suharyono and Sofian, L. A. (1988) Rumen microbial growth rate in relation to biological evaluation of feedstuffs. Proc. $3^{\text {rd }}$ Symp. on Application of Isotopes and Radiation, PAIR, BATAN, Jakarta 1097.

Hendratno, C; Tjiptosumirat, T and Sofian L.A (1989) Effective use of molasses blocks as supplements for Etawah Cross-bred goats. Proc. Conf. on Ruminants and Small ruminants, Research Inst. for Animal Production, Bogor 169.

Herrera M.; Rodero E.; Gutierrez M. J.; Pena F. and Rodero J. M. (1996) Application of multifactorial discriminant analysis in the morphostructural differentiation of Audalusian captive breeds. Small Ruminant Research. 22:39-47.

Jacob J. P.; Kunkle W. E.; Trevola R. S.; Miles R. D. and Mather F. B. (1997) Broiler litter. Part I. A feed ingredient for ruminants. University of Florida Cooperative Extension Service. IFAS Fact Sheet Ps13. 
Kelly W.R (1980) Veterinary clinical diagnosis 3rd edition. Losndon. Bailliere Tindall.

Leng R. A.; Preston T. R.; Sansoucy R. and George Kunju P. L.(1991) Multinutrient blocks as a strategic supplement for ruminants. World Animal Review 67:11-19.

NAPRI (1984) Highlights of Research Achievements on Animal Production. Science and Technology Briefing Lagos December 1984 pp. 3-17.

Nwechue N. F. (2000) Performance and carcass quality of West African Dwarf Sheep fed Siam weed (Chromelaena odorata) based diets. Ph. D. Thesis, University of Ibadan, Ibadan, Nigeria.

Ogunmola A. I. (1981) Physiological responses of Bos indicus and Bos Taurus females in modified and unmodified humid tropical climatic conditions. Ph. D. Thesis University of Ibadan, Ibadan, Nigeria.

Onwuka C. F. I. (1999) Molasses blocks as supplementary feed resources for ruminants. Arch. Zootech 48:89-94.

Orheruata, A.M and Olutogun, O (1994) Pre and post weaning phenotypic relationship between some N'Dama Cattle Linear measurement in the tropics. Nig. J. Anim. Prod. 21: 76-82.

Pagot J. (1992) Animal production in the tropics and subtropics. Published by Macmillan Education.

Preston T. R. and Leng R. A. (1984) Supplementation of diets based on fibrous residues and by-products. In: Sundstol F. and Owens E. (eds.) Straw and others fibrous by-products as feeds. Elsevier Publishing Co. pp 373-413.
Preston T. R. and Leng R. A. (1986) Matching livestock systems to available feed resources. Addis Ababa ILCA.

Radostits, O.M; Blood, D.C and Gay, C.C. (1997) Clinical examination and making a diagnosis. Veterinary Medicines. A textbook of the diseases of Cattle, Sheep, Pig, Goats and Horse. $8^{\text {th }}$ ed. W.B. Saunders Co. Ltd. London, Pp: 3-29.

Ricca R. and Combellas J. (1993) Influence of Multinutrient blocks on Live weight gain of young bulls grazing sorghum stubble. Livestock Res. Rural Dev. 5(3): 31 38.

Salako A. E. and Ngere L. O. (2002) Application of multifactorial discriminant analysis in the morphometric structural differentiation of West African Dwarf (WAD) and Yankasa Sheep in South West Nigeria. Nig. J. Anim. Prod. 29(2) 163-167.

Sansoucy R.; Aarta G. and Preston T. R. (1988) Molasses-urea blocks as multinutrient supplement for ruminants. In sugarcane as feed. Proceedings of an FAO experts consultation held in Santo Domingo, Dominican Republic 7-11 July 1986. FAO Animal Production and Health paper No 72. 319 pp.

Steel R. G. B. and Torrie J. H. (1980) Principle and procedures of statistics. McGraw Hill book Co. N.Y.

Tjiptosumirat, T; Hendratno, C; Widiajakusuma, R, and Sino, S (1990) Supplementation of urea - molasses blocks to increase production and reproductive performance of Etawa Cross-bred goats. Proc. $4^{\text {th }}$ Symp. on Application of Isotopes and Radiation. PAIR, BATAN, Jakarta 1169. 